\title{
ERRATUM
}

\section{Post-concussion Symptom Factors and Neuropsychological Outcomes in Collegiate Athletes - Erratum}

Erin Guty, AND Peter Arnett

doi: 10.1017/S135561771800036X. Published online by Cambridge University Press on 21 June 2018.

The paper by Guty and Arnett (2018) contains an error on page 684 that should be brought to the attention of readers. It is listed here, along with the incorrect and correct copy:

Incorrect copy: Received November 20, 2017; Final Revision March 30, 2018; Accepted April 2, 2018; First Published OnLine June 21, 2018

Correct copy: Received November 20, 2017; Final Revision March 30, 2018; Accepted April 4, 2018; First Published Online June 21, 2018

Cambridge University Press regrets the inconvenience that this error may have caused. The article has been updated with the correct copy. 